

\title{
Colonization of Beauveria bassiana (Balsamo) Vuillemin strains in maize (Zea mays L.) and their efficacy against stem borer Chilo partellus (Swinhoe)
}

\author{
S. RENUKA, B. RAMANUJAM* and B. POORNESHA
}

ICAR-National Bureau of Agricultural Insect Resources, H.A. Farm Post, Bellary Road, Bengaluru - 560 024, Karnataka, India

"Corresponding author E-mail: bonamramanujam58@gmail.com

\begin{abstract}
Glasshouse experiments were conducted to study the endophytic ability of six strains of entomopathogenic fungi Beauveria bassiana in maize leaf and stem tissues when applied through foliar sprays of oil formulations. B. bassiana treated and untreated control plants were artificially infested with second instar larvae of Chilo partellus to assess the stem borer damage. The variation in per cent colonization and persistence was observed in all the six strains in stem and leaf tissues of maize. The mean per cent colonization was observed in older stem tissues (16.67-46.67 \%), in young stem tissues (22.22-52.22\%), in older leaf tissues (25.56-47.78 \%) and in young leaf tissues (31.11-57.78\%). Evaluation of six B. bassiana strains, revealed that the isolate Bb-45 recorded the highest mean colonization in mature stem (46.67\%), mature leaf (47.78\%) and also in relatively younger stem $(52.22 \%)$. The Bb-5a isolate also exhibited highest mean colonization in young leaf tissues $(57.78 \%)$. Lower percentage of dead hearts $(2.2-11.1 \%)$ and lower stem tunneling $(2.7-4.3 \mathrm{~cm} /$ plant) was observed significantly in B. bassiana treated plants as compared to the untreated control plants $(28.86 \%$ of dead hearts and $13.41 \mathrm{~cm} /$ plant stem tunneling).
\end{abstract}

KEY WORDS: Beauveria bassiana, Biocontrol, Chilo partellus, Endophyte, Entomopathogenic fungus, Maize

(Article chronicle: Received: 14.01.2017; Revised: 25.03.2017; Accepted: 31.03.2017)

\section{INTRODUCTION}

The stem borer Chilo partellus (Swinhoe) is one of the important insect pests of maize (Zea mays L.) in India. It has been reported mainly during kharif season in places like Assam, Andhra Pradesh, Bihar, Gujarat, Haryana, Himachal Pradesh, Karnataka, Madhya Pradesh, Maharashtra, Tamil Nadu and Uttar Pradesh. Depending on the ecological zone, the severity of the damage varies. In India, the pest also infests other crops like, finger millet, pearl millet, rice, sorghum, sugarcane and wheat and it also causes considerable damage to the crop (Jalali and Singh, 2003). Control of stem borers is extremely difficult using chemical insecticides because of the cryptic life cycle of the pest. In the recent years, biological control of insect pests using endophytic entomopathogenic fungi, Beauveria bassiana (Balsamo) Vuillemin has been receiving research attention. Some strains of B. bassiana were reported to colonize in various crop plants such as maize (Bing and Lewis, 1991), tomato (Leckie, 2002), coffee (Posada and Vega, 2006), date palm (Go'mez- Vidal et al., 2006), banana (Akello et al., 2007) and sorghum (Tefera and Vidal, 2009). Endophytic B. bassiana has the ability to infect insect pests like European corn borer (Ostrinia nubilalis) in maize (Bing and Lewis 1991, 1992) and banana weevil (Cosmopolites sordidus) in banana (Akello et al., 2008). Entomopathogenic fungal strains as endophytes in the plant system have several advantageous for biological control of insect pests as they give season long protection against cryptic pests like borers and are cost effective. Exploitation of endophytism of $B$. bassiana offers an alternative strategy for borer pest management.

In our earlier studies through laboratory bioassay (Renuka et al., 2015; 2016), six promising strains of B. bassiana (NBAII-Bb-5a, 7, 14, 19, 23 and 45) were identified against $C$. partellus and were established as endophytes in maize stem and leaf tissues by artificial inoculation through foliar sprays of conidial suspensions.

The current study was undertaken to enhance the endophytic colonization in maize through oil formulations and to evaluate these oil formulations of these six endophytic strains of $B$. bassiana against maize stem borer, $C$. partellus under glasshouse conditions. 


\section{MATERIALS AND METHODS}

Two glasshouse experiments were conducted at National Bureau of Agricultural Insect Resources (NBAIR), Bengaluru, India during October 2015 to January 2016. The first experiment was conducted to check the endophytic ability of six B. bassiana strains in maize when applied as oil formulations and the second experiment was conducted to study the effect of endophytically established $B$. bassiana strains on the stem borer, Chilo partellus infestation.

\section{Host plant}

Maize variety Nithyashree seeds were obtained from University of Agricultural Sciences, Bengaluru, Karnataka, India for this study. Maize seeds were surface sterilized with 3\% sodium hypochlorite for two minutes, then with $70 \%$ ethanol for two minutes and rinsed twice with sterile distilled water. The surface sterilized seeds were then dried and sown in plastic pots (30 cm diameter) containing $5 \mathrm{~kg}$ of autoclaved sterile soil. In the first experiment, three replications for each treatment (ten plants per replication) were maintained. In the second experiment, three replications for each treatment (five plants per replication) were maintained. The pots were kept at $21-22^{\circ} \mathrm{C}, 60-80 \% \mathrm{RH}$ in the glasshouse and watered frequently.

\section{Insect and fungal cultures}

A starter culture of $C$. partellus larvae was obtained from ICAR-NBAIR (National Bureau of Agricultural Insect Resources) and reared on artificial diet in the laboratory at $25-27^{\circ} \mathrm{C}$ (Ballal et al., 1995). Six promising strains of B. bassiana (NBAII-Bb-5a, 7, 14, 19, 23 and 45) were isolated from different insect hosts and soil samples from different regions of India were maintained at NBAIR culture repository, Bengaluru were used in this study (Table 1).

\section{Preparation of oil formulation of fungal cultures}

Conidiated rice was produced by inoculating 4 days old shaker culture to sterilized rice bag and incubated for 15 days at $26 \pm 1^{\circ} \mathrm{C}$. Conidia of each strain were harvested from the rice by passing through a sieve $(300 \mu \mathrm{m}) .100 \mathrm{ml}$ of the oil formulations of each strain was prepared using liquid paraffin oil $(96 \mathrm{ml})$, skim milk powder $(1 \mathrm{~g})$, poly eth- ylene glycol (1ml), conidia (2g) and Tween-80 (15 drops). The initial conidial concentration of the B. bassiana strains in the oil formulation ranged from $0.03-3.3 \times 10^{10}$ conidia/ $\mathrm{ml}$. The conidial concentration in the oil formulations of each strain was adjusted to $1 \times 10^{8}$ conidia/ml by diluting with water and using Neaubauer haemocytometer just before foliar spray.

\section{Plant inoculation}

The oil formulation of each strain $\left(1 \times 10^{8}\right.$ conidia / $\mathrm{ml})$ was sprayed on maize seedlings $(5 \mathrm{ml} /$ seedling) with a hand sprayer at 15 and 30 days after germination. The control plants were sprayed with diluted oil formulation $(10 \mathrm{ml}$ of oil formulation in 1L of water) devoid of conidia. Pots were covered with aluminum foil at the top region to avoid conidial contact with soil.

\section{Colonization of Beauveria bassiana in maize stem and leaf tissues}

In the first experiment, the establishment of six $B$. bassiana strains as endophytes in maize was examined at 15, 30, 45, 60 and 75 DAFS (days after first spray). At each sampling period, three plants were randomly selected from each treatment. Plants were uprooted and washed thoroughly under running tap water. From each plant, two older leaves (sprayed leaves) and two younger leaves (unsprayed/ or newly emerged leaves) and two pieces of older stem (sprayed stem) and two pieces of growing tip of the stem (unsprayed/or newly grown stem) were collected.

\section{By plating technique}

The leaf and stem samples were surface sterilized with $1 \%$ sodium hypochlorite for 5 minutes, with $70 \%$ ethanol for 30 seconds followed by three washes in sterilized distilled water for a minute each. Then the samples were cut into $5 \mathrm{~mm}$ bits and transferred into petri dishes containing Sabouraud's Dextrose Yeast extract Agar (SDYA) medium (Dextrose-40g, Mycological peptone-10g, yeast extract-5g, agar- $20 \mathrm{~g}$ in $1000 \mathrm{ml}$ of distilled water) containing chloramphenicol, streptomycin sulphate, tetracyclin and penicillin $(0.1 \mathrm{gm} / \mathrm{liter})$ to avoid bacterial contamination. $100 \mu \mathrm{l}$ of final rinsed water was plated on SDYA plates to check the effectiveness of surface sterilization. The plates were

\section{Table 1. List of promising strains of Beauveria bassiana}

\begin{tabular}{|l|l|l|l|l|}
\hline S1 no. & Strains Code & Source & Location & Genbank accession number \\
\hline 1 & NBAII-Bb5a & Hypothenemus hampei (Coffee berry borer) & Madikeri, Karnataka & JF837134 \\
\hline 2 & NBAII-Bb7 & Plocaederus ferrugines (Cashew root \& stem borer) & Puttur, Karnataka & JF837097 \\
\hline 3 & NBAII-Bb14 & Unknown insect & Doddaballapura, Karnataka & JF837092 \\
\hline 4 & NBAII-Bb19 & Banana rhizosphere soil & Trichy, Tamil Nadu & KC121555 \\
\hline 5 & NBAII-Bb23 & Maruca testulalis (Legume pod borer) & Karaikal, Puducherry & JF837082 \\
\hline 6 & NBAII-Bb45 & Carrot rhizosphere soil & Nedugula, Tamil Nadu & JF837094 \\
\hline
\end{tabular}


maintained at $26 \pm 1{ }^{\circ} \mathrm{C}$ in a biological oxygen demand (BOD) incubator for seven days for the development of fungal growth. The fungal growth appeared from the plated bits was examined under microscope for confirmation of B. bassiana growth. Percent colonization of each strain was calculated based on the number of bits in older and young stem \& older and young leaf bits yielding B. bassiana growth at different sampling periods and total number of bits plated. The percent colonization data were statistically analyzed using two-way ANOVA (analysis of variance) using SPSS 16 version.

\section{PCR analysis}

Genomic DNA was extracted from surface sterilized treated leaf and stem bits as well as untreated maize at 15 , $30,45,60$, and 75 DAFS as per the instruction manual of CTAB method (Cetyl Trimethyl Ammonium Bromide). DNA was extracted from 300mg of leaf/stem samples. Each sample was ground in $9 \mathrm{ml}$ of pre-warmed CTAB extraction buffer and was kept for incubation at $65^{\circ} \mathrm{C}$ for $60-90$ minutes in water bath with occasional stirring. After that, the samples were allowed to cool at room temperature and $5 \mathrm{ml}$ of chloroform and isoamyl alcohol (24:1) was added to each tube. Samples were then centrifuged at $7000 \mathrm{rpm}$ for 15 minutes at $20^{\circ} \mathrm{C}$. The supernatant was carefully transferred into new tube containing $25 \mu \mathrm{l}$ RNase $(20 \mathrm{mg} / \mathrm{ml})$ and was incubated at room temperature for 30 minutes. $6 \mathrm{ml}$ of ice-cold isopropanol was added to each tube and mixed gently by inversion to get a white fluffy DNA precipitate. The DNA precipitate was centrifuged at $7000 \mathrm{rpm}$ at $4^{\circ} \mathrm{C}$ for 10 minutes. The supernatant was discarded and to the pellet, $8 \mathrm{ml}$ of cold CTAB wash buffer was added and kept for 20 minutes at room temperature. The samples were centrifuged at $7000 \mathrm{rpm}$ for 3 minutes at $4^{\circ} \mathrm{C}$. The precipitated DNA was washed with $9 \mathrm{ml}$ of cold CTAB wash buffer and $70 \%$ ethanol separately at $7000 \mathrm{rpm}$ for 10 minutes at $4^{\circ} \mathrm{C}$. DNA pellets were dissolved in $100 \mu$ of TE buffer $(10 \mathrm{mM}$ Tris- $\mathrm{HCl}+0.1 \mathrm{mM}$ EDTA at $\mathrm{pH} 8.0$ ) and were stored at $-20^{\circ} \mathrm{C}$.

The DNA samples were assessed by PCR using B. bassiana specific SCAR (Sequence-characterized amplified region) primer (SCA15 ${ }_{441}$ (F $5^{1}$ TTCCGAACCCGGTTAAGAGAC $3^{1}$, R $5^{1}$ TTCCGAACCCATCATCCTGC $3^{1}$ ) to amplify the target DNA sequence of $B$. bassiana. $50 \mu 1$ of PCR mixture consisting of 50ng of DNA, SCAR primers (50 pmol each), $1.25 \mathrm{mM}$ of each of the dATP, dGTP, dCTP, dTTP, 2.5 units of Taq DNA polymerase, $5 \mu$ l of 10x Taq buffer, $2.5 \mathrm{Mm} \mathrm{MgCl}_{2}$ and made upto $50 \mu \mathrm{l}$ volume by using sterile de-ionized water. Biorad Thermal cycler was used to carry out the $\mathrm{PCR}$ program with initial denaturation at $95^{\circ} \mathrm{C}$ for 5 minutes, followed by 35 cycles of denaturation at 94
${ }^{\circ} \mathrm{C}$ for 1 minute, annealing at $52{ }^{\circ} \mathrm{C}$ for 1 minute, extension at $72^{\circ} \mathrm{C}$ for 1 minute and final extension at $72^{\circ} \mathrm{C}$ for $10 \mathrm{~min}-$ utes and store at $4{ }^{\circ} \mathrm{C} .1 .4 \%$ agarose gel with ethidium bromide was used to visualize the PCR product. The molecular weight of the amplified fragment size was calculated using ladder (Ling et al., (1987).

\section{Artificial infestation of maize plants with Chilo partel- Ius}

In the second experiment, B. bassiana treated and untreated maize seedlings were artificially infested with the second instar larvae of $C$. partellus after five days of second spray ( 35 days after germination). Five numbers of C. partellus (second instar larvae) were carefully placed into the inner leaf whorl of each seedling using a camel hair brush. The infested maize plants were maintained at $25-30^{\circ} \mathrm{C}$ temperature and $60-80 \% \mathrm{RH}$ in the glasshouse.

\section{Damage assessment}

Foliar damage was assessed after one week of release of C. partellus larvae. Damage assessment was made by using a scale from 0 to 5 score (Odindo et al., 1992). Scores $0=$ damage free; $1=$ covered $1 \%$ damage of the leaf; $2=$ damage of upto $5 \%$ of the leaf; $3=$ covering $5-10 \%$ damage of the leaf; $4=10-15 \%$ of the leaf; and $5=$ covering $>15 \%$ damage of the leaf area. The data of foliar damage were subjected to Kruskall-Wallis non-parametric analyses. The rank sums were used to determine significant differences between means at $\mathrm{P}<0.05$ (Dunn, 1964).

Data on the plants showing dead hearts and exit holes in each plant were recorded after four weeks of larval release. The plants were split opened and the length of stem tunneling caused by the larvae in each plant was recorded (centimeters per plant). The number of live larvae and pupae per plant were also recorded. The data on dead hearts was arcsine transformed, analysed by WASP 2.0 (Web Agri Stat Package) and expressed in percentage. The data of exit holes and live larvae/pupae were analysed by WASP 2.0 (Web Agri Stat Package) and expressed per plant.

\section{RESULTS AND DISCUSSION}

\section{Establishment of endophytic colonization of Beauveria bassiana}

\section{Plate count method}

Treated stem and leaf samples (from both older and young tissue samples) when plated showed white hyphal growth bits showed typical single celled conidia with flask shaped phialides of $B$. bassiana under light microscope which establishes that $B$. bassiana was able to colonize the stem and leaf tissues of maize thus proving its endophytic nature. The untreated control bits did not show such hyphal 
growth (Fig. 1). The percent colonization and persistence of six strains of B. bassiana in stem (older \& young) and leaf (older \& young) tissues of maize are presented in Table $2 \&$ 3. All six strains showed variation in per cent colonization and persistence in the maize tissue (stem and leaf).

Data on the per cent colonization (days after first spray) was $16.67-46.67 \%$ in mature stems whereas it was 22.22-52.22 \% in tender stem tissues (Table 2). In older leaf tissues the average per cent colonization ranged from $25.56-47.78 \%$ and in younger leaf tissues it was 31.11$57.78 \%$ (Table 3 ). Bb-45 showed that it is an efficient tissue colonizer by recording highest mean colonization in mature stem (46.67\%) and also in young stem (52.22\%) (Table 2). Similar results were obtained in leaf tissue with $\mathrm{Bb}-5 \mathrm{a}$ and the mean colonization recorded was $45.55 \%$ in mature leaf and $57.78 \%$ in tender leaf (Table 3). B. bassiana colonization was not observed in control (untreated) leaf and stem tissues.

Among different sampling periods, 15 and 30 DAFS showed enhanced mean occupancy in either young or old tissues of stem and leaf. Thereafter, the percent colonization was gradually decreased. In the mean percent coloni- zation (isolates) of all the isolates, the higher colonization was observed in older (53.96\% and 53.17\%) and younger (63.49\% and 57.14\%) stem tissues at 15 and 30 DAFS respectively. In leaf tissues, the higher colonization was observed in older (58.72\% and $57.14 \%)$ and younger $(63.48 \%$ and $63.49 \%$ ) leaf tissues at 15 and 30 DAFS respectively.

Bb-5a strain showed colonization up to 60 DAFS in older stem tissues however in young stem tissues the presence of Bb-7 was observed up to 75 DAFS. The isolates Bb$5 \mathrm{a}, \mathrm{Bb}-19$ and Bb-45 showed colonization up to 60 DAFS in older leaf tissues whereas in young leaf tissues Bb-7 and $\mathrm{Bb}-45$ was present as endophyte up to 75 DAFS.

The results do establish that $\mathrm{Bb}-5 \mathrm{a}$ is able to efficiently colonize mature stem tissues $(88.89 \%)$ at 15 DAFS, however Bb-45 proved a better colonizer (100.0\%) at 30 DAFS in mature stem tissues. But in young stem tissues, $\mathrm{Bb}-7$ and Bb-23 exhibited higher per cent colonization (100.0\%) at 15 DAFS but at 30DAFS Bb-45 100\% colonization. In mature leaf tissues, $\mathrm{Bb}-5 \mathrm{a}$ recorded higher per cent colonization $(88.89 \%)$ at 30 DAFS and in young leaf tissues, Bb-5a and $\mathrm{Bb}-7(100.0 \%)$ showed maximum per cent colonization at 15 DAFS respectively.
Stem bits

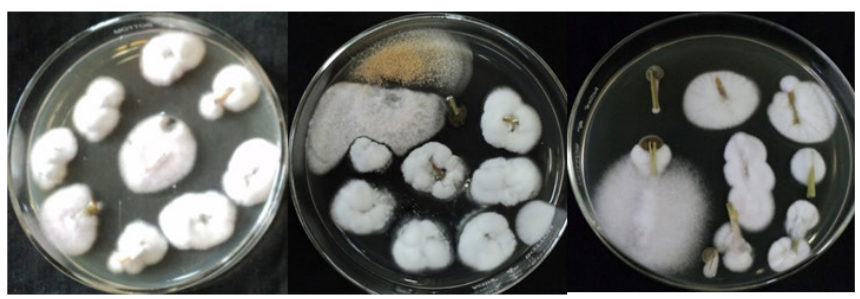

Bb5a

Bb7

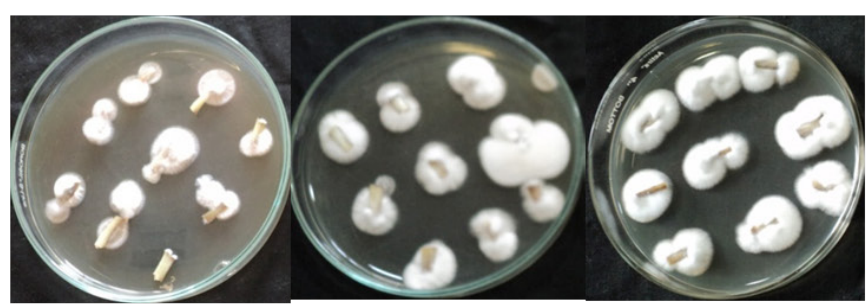

Bb19
$\mathbf{B b 2 3}$

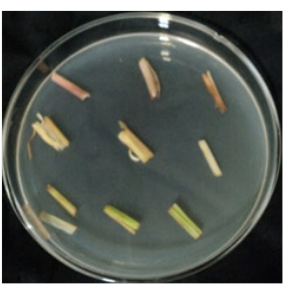

Untreated control without fungal growth
Leaf bits

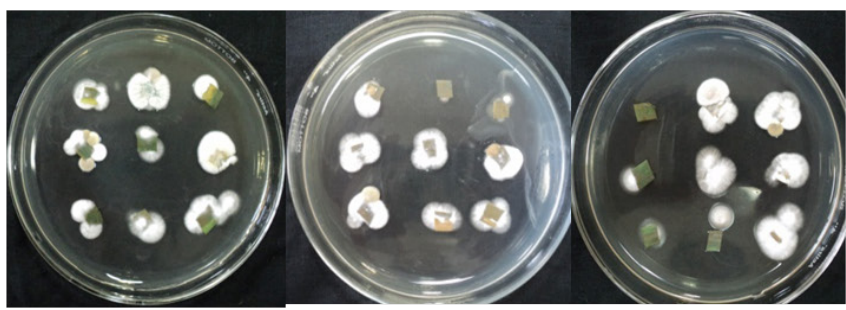

Bb5a

Bb7

Bb14

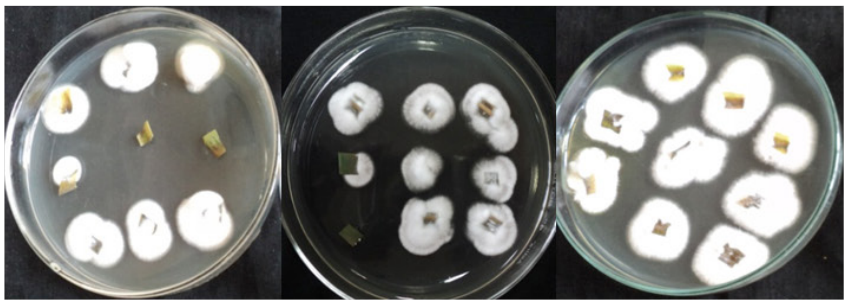

Bb19

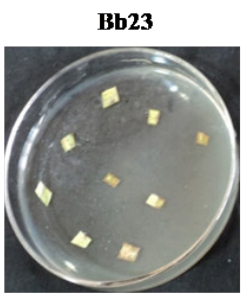

Untreated control without fungal growth

Fig. 1. Different isolates of Beauveria bassiana showing fungal growth from the treated stem and leaf bits. 
Table 2. Colonization of Beauveria bassiana in stem tissues (older/young) of maize (Percentage)

\begin{tabular}{|c|c|c|c|c|c|c|c|c|c|c|c|c|}
\hline \multicolumn{13}{|c|}{ Days after first spray } \\
\hline & \multicolumn{6}{|c|}{ Older stem tissues } & \multicolumn{6}{|c|}{ Young stem tissues } \\
\hline Isolates & 15 & 30 & 45 & 60 & 75 & Mean & 15 & 30 & 45 & 60 & 75 & Mean \\
\hline $\mathrm{Bb5a}$ & $88.89^{\mathrm{a}}$ & $50.00^{\mathrm{c}}$ & $11.11^{\mathrm{d}}$ & $11.11^{\mathrm{d}}$ & 0.00 & $32.22^{\mathrm{B}}$ & $88.89^{\mathrm{a}}$ & $77.78^{\mathrm{a}}$ & $33.33^{c}$ & $5.56^{\mathrm{c}}$ & 0.00 & $41.11^{\mathrm{B}}$ \\
\hline $\mathrm{Bb} 7$ & $72.22^{\mathrm{b}}$ & $33.33^{\mathrm{c}}$ & $16.67^{\mathrm{d}}$ & 0.00 & 0.00 & $24.44^{\mathrm{B}}$ & $100.00^{\mathrm{a}}$ & $11.11^{\mathrm{c}}$ & $11.11^{\mathrm{c}}$ & $16.67^{\mathrm{c}}$ & $5.56^{\mathrm{c}}$ & $28.89^{\mathrm{B}}$ \\
\hline $\mathrm{Bb} 14$ & $5.55^{\mathrm{d}}$ & $66.67^{b}$ & $11.11^{\mathrm{d}}$ & 0.00 & 0.00 & $16.67^{\mathrm{C}}$ & $11.11^{\mathrm{c}}$ & $66.67^{\mathrm{b}}$ & $22.22^{\mathrm{c}}$ & $11.11^{\mathrm{c}}$ & 0.00 & $22.22^{\mathrm{B}}$ \\
\hline $\mathrm{Bb} 19$ & $72.22^{\mathrm{b}}$ & $61.11^{\mathrm{b}}$ & $5.56^{d}$ & 0.00 & 0.00 & $27.78^{\mathrm{B}}$ & $55.55^{\mathrm{b}}$ & $66.67^{\mathrm{b}}$ & $22.22^{\mathrm{c}}$ & 0.00 & 0.00 & $28.89^{\mathrm{B}}$ \\
\hline $\mathrm{Bb} 23$ & $44.44^{\mathrm{c}}$ & $61.11^{\mathrm{b}}$ & $16.67^{\mathrm{d}}$ & 0.00 & 0.00 & $24.44^{\mathrm{B}}$ & $100.00^{\mathrm{a}}$ & $77.78^{a}$ & $33.33^{\mathrm{c}}$ & $11.11^{\mathrm{c}}$ & 0.00 & $44.44^{\mathrm{A}}$ \\
\hline $\mathrm{Bb} 45$ & $94.44^{\mathrm{a}}$ & $100.00^{\mathrm{a}}$ & $38.89^{\mathrm{c}}$ & 0.00 & 0.00 & $46.67^{\mathrm{A}}$ & $88.89^{\mathrm{a}}$ & $100.00^{\mathrm{a}}$ & $66.67^{\mathrm{b}}$ & $5.56^{\mathrm{c}}$ & 0.00 & $52.22^{\mathrm{A}}$ \\
\hline Control & 0.00 & 0.00 & 0.00 & 0.00 & 0.00 & 0.00 & 0.00 & 0.00 & 0.00 & 0.00 & 0.00 & 0.00 \\
\hline Mean & $53.96_{A}$ & $53.17_{\AA}$ & $14.28_{B}$ & $1.58_{\mathrm{C}}$ & 0.00 & & $63.49_{A}$ & $57.14_{A}$ & $26.98_{B}$ & $7.14_{C}$ & $0.79_{C}$ & \\
\hline \multicolumn{3}{|c|}{ CDvalues@0.01 } & $\mathrm{T}=$ & 8.93 & & & \multicolumn{3}{|c|}{ CD values @ 0.01} & $\mathrm{~T}=$ & 13.39 & \\
\hline & & & $\mathrm{D}=$ & 7.54 & & & & & & $\mathrm{D}=$ & 11.32 & \\
\hline & & & $\mathrm{TxD}=$ & 19.97 & & & & & & $\mathrm{TxD}=$ & 29.95 & \\
\hline
\end{tabular}

Values in columns followed by the different letter $(\mathrm{a}, \mathrm{b}, \mathrm{c})$ are significantly different with each other according to LSD (P $<0.01)$

Values in columns followed by the different letter (A, B) are significantly different with each other according to LSD (P $<0.01$ )

Values in columns followed by the different letter (sub script A, B) are significantly different with each other according to LSD (P $<0.01$ )

Table 3. Colonization of Beauveria bassiana in leaf tissues (older/young) of maize (Percentage)

\begin{tabular}{|c|c|c|c|c|c|c|c|c|c|c|c|c|}
\hline \multicolumn{13}{|c|}{ Days after first spray } \\
\hline & \multicolumn{6}{|c|}{ Older leaf tissues } & \multicolumn{6}{|c|}{ Young leaf tissues } \\
\hline Isolates & 15 & 30 & 45 & 60 & 75 & Mean & 15 & 30 & 45 & 60 & 75 & Mean \\
\hline $\mathrm{Bb} 5 \mathrm{a}$ & $77.77^{\mathrm{a}}$ & $88.89^{\mathrm{a}}$ & $50.00^{\mathrm{b}}$ & $11.11^{\mathrm{c}}$ & 0.00 & $45.55^{\mathrm{A}}$ & $100.00^{\mathrm{a}}$ & $88.89^{\mathrm{a}}$ & $66.67^{\mathrm{a}}$ & $33.33^{\mathrm{b}}$ & 0.00 & $57.78^{\mathrm{A}}$ \\
\hline $\mathrm{Bb} 7$ & $72.22^{\mathrm{a}}$ & $61.11^{\mathrm{a}}$ & $38.89^{\mathrm{b}}$ & 0.00 & 0.00 & $34.44^{\mathrm{B}}$ & $100.00^{\mathrm{a}}$ & $77.78^{\mathrm{a}}$ & $44.44^{\mathrm{b}}$ & $11.11^{\mathrm{b}}$ & $5.56^{\mathrm{b}}$ & $47.78^{\mathrm{A}}$ \\
\hline $\mathrm{Bb} 14$ & $55.55^{\mathrm{b}}$ & $61.11^{\mathrm{a}}$ & $22.22^{\mathrm{c}}$ & 0.00 & 0.00 & $27.78^{\mathrm{B}}$ & $55.55^{\mathrm{a}}$ & $66.67^{\mathrm{a}}$ & $33.33^{\mathrm{b}}$ & $5.56^{\mathrm{b}}$ & 0.00 & $32.22^{\mathrm{B}}$ \\
\hline $\mathrm{Bb} 19$ & $83.33^{\mathrm{a}}$ & $55.56^{\mathrm{b}}$ & $11.11^{\mathrm{c}}$ & $22.22^{\mathrm{c}}$ & 0.00 & $34.44^{\mathrm{B}}$ & $66.66^{\mathrm{a}}$ & $55.56^{\mathrm{a}}$ & $33.33^{\mathrm{b}}$ & $5.56^{\mathrm{b}}$ & 0.00 & $32.22^{\mathrm{B}}$ \\
\hline $\mathrm{Bb} 23$ & $55.55^{\mathrm{b}}$ & $55.56^{\mathrm{b}}$ & $16.67^{\mathrm{c}}$ & 0.00 & 0.00 & $25.56^{\mathrm{B}}$ & $44.44^{\mathrm{b}}$ & $77.78^{\mathrm{a}}$ & $22.22^{\mathrm{b}}$ & $11.11^{\mathrm{b}}$ & 0.00 & $31.11^{\mathrm{B}}$ \\
\hline $\mathrm{Bb} 45$ & $66.66^{\mathrm{a}}$ & $77.78^{\mathrm{a}}$ & $83.33^{\mathrm{a}}$ & $11.11^{\mathrm{c}}$ & 0.00 & $47.78^{\mathrm{A}}$ & $77.77^{\mathrm{a}}$ & $77.78^{\mathrm{a}}$ & $66.67^{\mathrm{a}}$ & $22.22^{\mathrm{b}}$ & $16.67^{\mathrm{b}}$ & $52.22^{\mathrm{A}}$ \\
\hline Control & 0.00 & 0.00 & 0.00 & 0.00 & 0.00 & 0.00 & 0.00 & 0.00 & 0.00 & 0.00 & 0.00 & 0.00 \\
\hline Mean & $58.72_{\mathrm{A}}$ & $57.14_{A}$ & $31.74_{B}$ & $6.34_{C}$ & 0.00 & & $63.48_{A}$ & $63.49_{A}$ & $38.09_{\mathrm{B}}$ & $12.69_{\mathrm{C}}$ & $3.17_{\mathrm{C}}$ & \\
\hline \multicolumn{3}{|c|}{ CD values@0.01 } & $\mathrm{T}=$ & 13.31 & & & \multicolumn{3}{|c|}{ CD values@ 0.01} & $\mathrm{~T}=$ & 20.64 & \\
\hline & & & $\mathrm{D}=$ & 11.25 & & & & & & $\mathrm{D}=$ & 17.44 & \\
\hline & & & $\mathrm{TxD}=$ & 29.78 & & & & & & $\mathrm{TxD}=$ & 46.16 & \\
\hline
\end{tabular}

Values in columns followed by the different letter $(a, b, c)$ are significantly different with each other according to LSD (P $<0.01)$

Values in columns followed by the different letter (A, B) are significantly different with each other according to LSD (P $<0.01)$

Values in columns followed by the different letter (sub script A, B) are significantly different with each other according to LSD $(\mathrm{P}<0.01)$

Earlier reports (Akutse et al., 2013; Biswas et al., 2013) suggest that the differences in colonization rate between B. bassiana strains could be attributed to variations in growth rate and the tissue colonizing ability (endophytic) of each strain that is associated with the host plant. Posada and Vega, 2005 (in cacao), Akutse et al., 2013 (in broad/ common bean) and Biswas et al., 2013 (in white jute) reported similar differences in colonization frequency among B. bassiana isolates. Inoculation techniques and kind of formulation may also influence on colonization frequency. In the present study, B. bassiana strains exhibited better tissue colonizing ability in mature/young stem and leaf tissues when they were applied as oil formulation through foliar application. In another study (Renuka et al., 2016) oil formulation spray of $B$. bassiana isolates exhibited better endophytic ability when compared to aqueous conidial suspension spray. This might be due to loss of viability, de- creased conidial germination on leaf surfaces. To enhance the germination and viability of the fungus on the plant surface oil formulations were supplemented with additives like surfactants, humectants, stickers as well as nutrients (Burges, 1998). In the present study, higher per cent colonization of the fungus may be due to presence of liquid paraffin oil which increases the viability of conidia, skim milk powder which acts as a nutrient as well as sunscreen, poly ethylene glycol as a stabilizer and Tween-80 as a surfactant. These additives must have increased the survival of conidia and germination on the leaf surface, which would have led to multiple entries of the fungus in to the plant tissues.

The recovery of $B$. bassiana from older stem/leaf tissues (developed before spraying) and young stem/leaf tissues (developed after spraying) indicates that it is able to spread internally in the stem and leaf tissues of maize. Not 
much is known about the mode of entry and movement of the entomopathogenic fungus within the maize plant, it is suggested that it may spread throughout the maize system by passive movement through xylem vessels (Wagner and Lewis, 2000). It was observed that the persistence of inoculated fungus decreased with increase in plant age. It could be attributed to decreased availability of nutrients during plant maturation time, competition between the inoculated fungi and other endophytic microbes in corn system or due to host response to the fungus (Posada et al., 2007).

\section{By PCR technique}

The genomic DNA extracted from $B$. bassiana treated maize stem and leaf (older and young tissue samples) tissues were amplified using B. bassiana specific SCAR primer SCA $15_{441}$ at $450 \mathrm{bp}$ (Fig 2 and 3). It failed to amplify the DNA extracted from untreated control leaf and stem tissues. This indicated that, the SCAR primer did not bind to any other plant genomic DNA and it is highly specific towards $B$. bassiana genomic DNA. The presence or absence of $B$. bassiana was observed at 15, 30, 45, 60 and 75 DAFS sampling periods. The positive results of colonization of six strains of $B$. bassiana in stem and leaf (from both older and young tissue samples) tissues observed in plating technique were confirmed by the PCR amplification.
Lane 1 to 18 (Fig. 2): 1-100bp ladder, 2- Bb5a older stem, 3- Bb5a young stem, 4-Bb5a older leaf, 5- Bb5a young leaf, 6- $\mathrm{Bb} 7$ older stem, 7- Bb7 young stem, 8-Bb7 older leaf, 9- Bb7 young leaf, 10- Bb14 older stem, 11Bb14 young stem, 12-Bb14 older leaf, 13- Bb14 young leaf, 14- Bb19 older stem, 15- Bb19 young stem, 16-Bb19 older leaf, 17- Bb19 young leaf, 18-100bp ladder. Lane 1 to 14 (Fig. 2): 1- 100 bp ladder, 2- Bb23 older stem, 3$\mathrm{Bb} 23$ young stem, 4-Bb23 older leaf, 5- Bb23 young leaf, 6- Bb45 older stem, 7- Bb45 young stem, 8-Bb45 older leaf, 9- Bb45 young leaf, 10- control older stem, 11- control young stem, 12-control older leaf, 13- control young leaf, 14-100bp ladder.

Lane 1 to 18 (Fig. 3): 1-Medium range ladder, 2Bb5a older stem, 3- Bb5a young stem, 4-Bb5a older leaf, 5- Bb5a young leaf, 6- Bb7 older stem, 7- Bb7 young stem, 8-Bb7 older leaf, 9- Bb7 young leaf, 10- Bb14 older stem, 11- Bb14 young stem, 12-Bb14 older leaf, 13- Bb14 young leaf, 14- Bb19 older stem, 15- Bb19 young stem, 16-Bb19 older leaf, 17- Bb19 young leaf, 18- Medium range ladder. Lane 1 to 14 (Fig. 3): 1- Medium range ladder, 2$\mathrm{Bb} 23$ older stem, 3- Bb23 young stem, 4-Bb23 older leaf, 5- Bb23 young leaf, 6- Bb45 older stem, 7- Bb45 young stem, 8-Bb45 older leaf, 9- Bb45 young leaf, 10- control
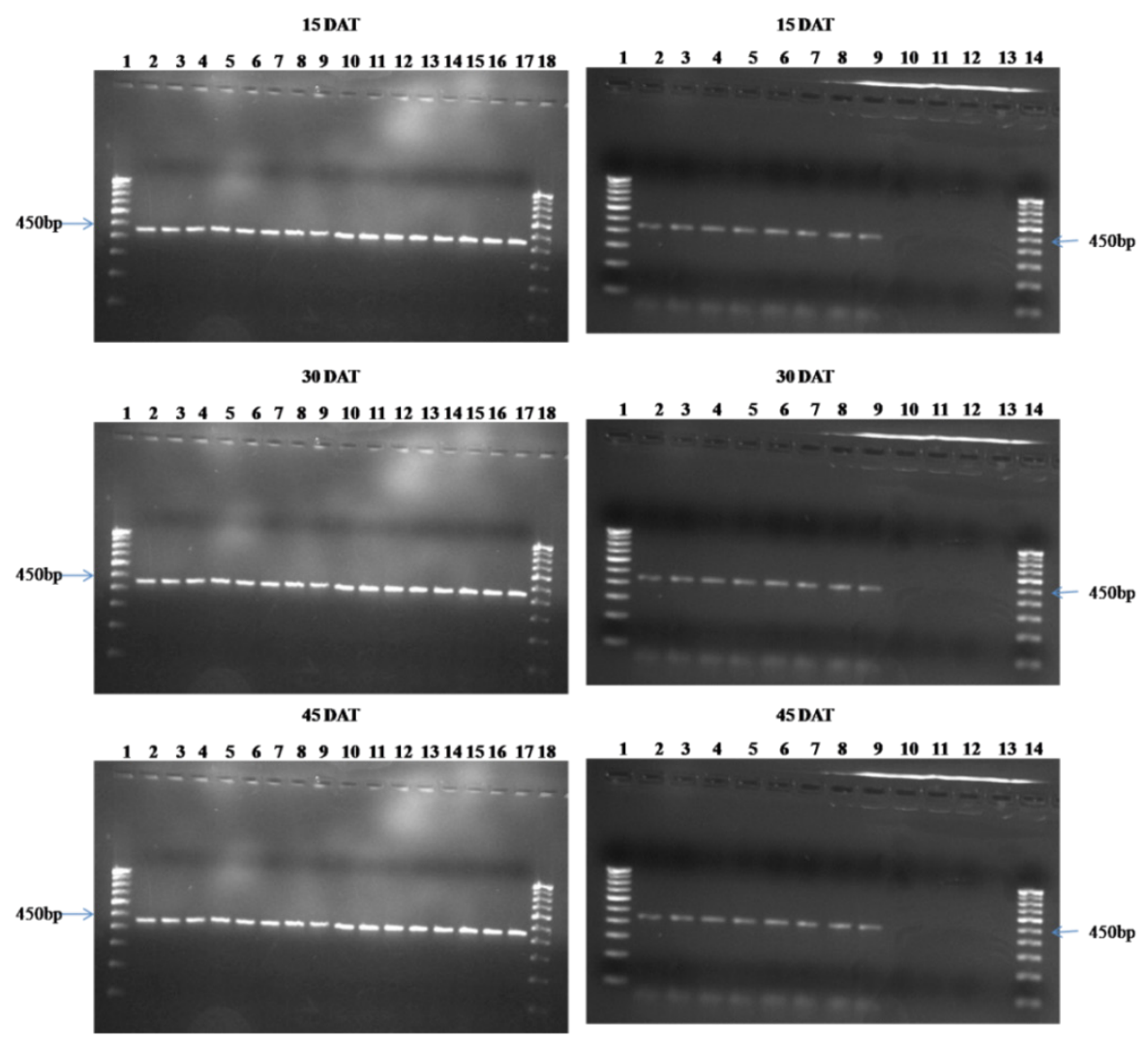

Fig. 2. PCR amplification of genomic DNA extracted from treated and untreated stem and leaf tissues of maize. 

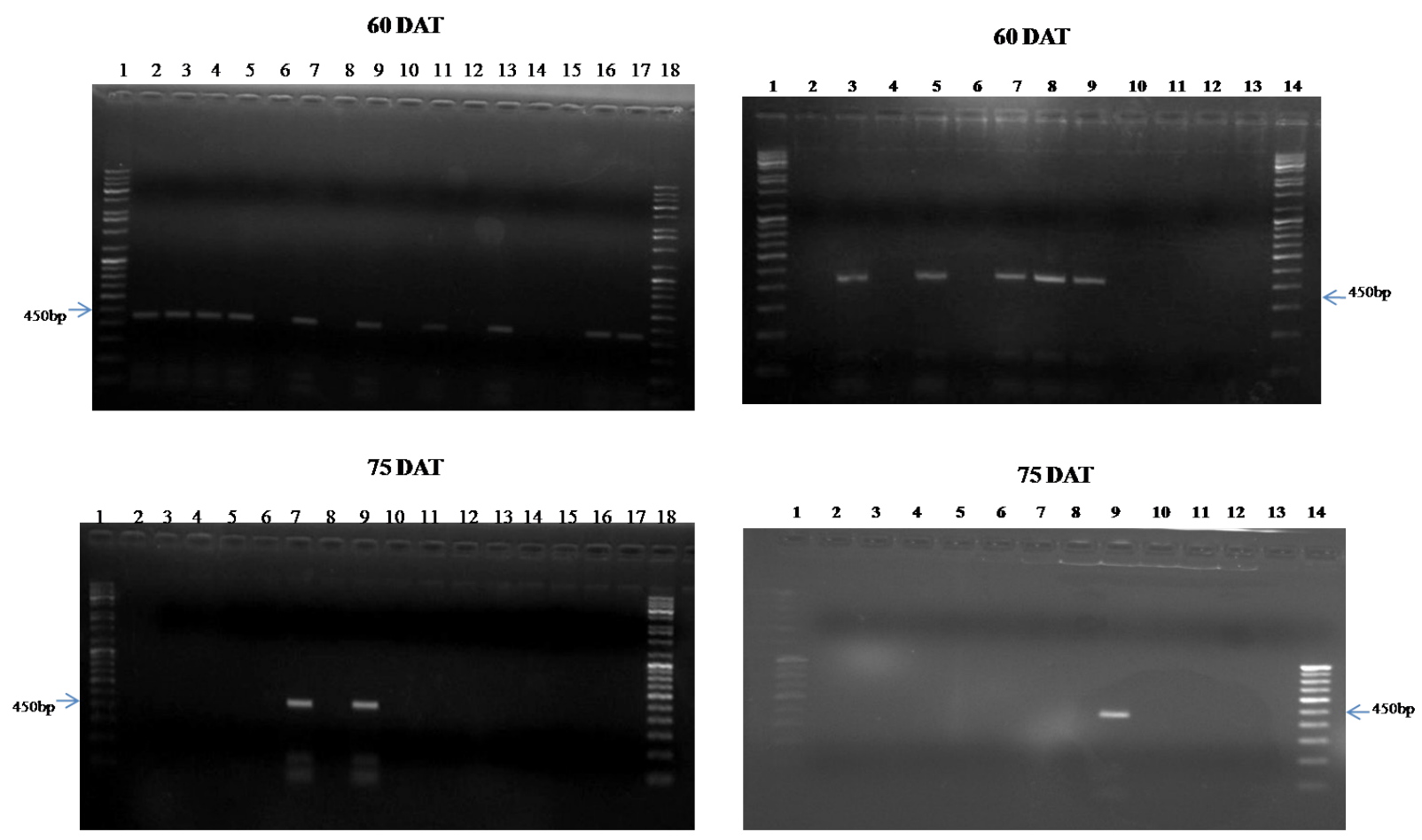

Fig. 3. PCR amplification of genomic DNA extracted from treated and untreated stem and leaf tissues of maize.

older stem, 11- control young stem, 12-control older leaf, 13- control young leaf, 14- Medium range ladder. 75 DAT, Lane 1 to 14 (Fig. 3): 1-100bp ladder, 2- Bb23 older stem, 3- Bb23 young stem, 4-Bb23 older leaf, 5- Bb23 young leaf, 6- Bb45 older stem, 7- Bb45 young stem, 8-Bb45 older leaf, 9- Bb45 young leaf, 10- control older stem, 11- control young stem, 12-control older leaf, 13- control young leaf, 14-100bp ladder.

\section{Effect of endophytic Beauveria bassiana strains on in- festation of Chilo partellus}

Data on foliar damage, percent dead hearts, stem tunneling per plant (cm), number of live larvae per plant, number of pupae per plant and exit holes per plant are presented in table 4. Among the six strains tested, less score of foliar damage was observed with Bb-5a (4.33), Bb-45 (5.67), Bb23 (8.83) and $\mathrm{Bb}-7$ (9.00) strains and were on par with each other (Table. 2). Bb-19 and Bb-14 strains showed higher foliar damage of 14.00 and 15.17 respectively and were statistically on par with each other. Control plants showed highest foliar damage of 20.00. Lowest percent dead hearts were observed in Bb-45 (2.2\%) and Bb-5a (2.2\%) treated plants and were on par with each other (Table 4). The other strains of Bb-7, Bb-23, Bb-14 and Bb-19 showed higher percentage of dead hearts $(6.66,6.66,11.13$ and 11.13 $\%$ respectively) and were on par with each other. Control plants showed highest percent of dead hearts (28.86\%).

All the six strains reduced the stem tunnelling caused by $C$. partellus and no significant differences with regard to the reduction of stem tunnelling were observed among the six strains tested and were statistically on par with each other. Bb-45 showed stem tunnelling of $2.69 \mathrm{~cm} /$ plant followed by Bb-23 (2.90 cm/plant), Bb-5a (3.03 cm/plant), Bb-7 (3.51 cm/plant), Bb-14 (4.17 cm/plant) and Bb-19 $(4.33 \mathrm{~cm} /$ plant $)$. Control plants showed highest tunnelling of $13.41 \mathrm{~cm} /$ plant.

There was a reduction in the recovery of the live $C$. partellus larvae and pupae from $B$. bassiana treated maize plants compared to untreated control plants (Table 4). No live larvae were recovered from Bb-45 treated plants. 0.07 larvae/ plant from Bb-23 treated plants, 0.13 larvae/ plant from $\mathrm{Bb}-5 \mathrm{a}$ and $\mathrm{Bb}-7$ treated plants, 0.27 larvae/ plant from $\mathrm{Bb}-14$ and $\mathrm{Bb}-19$ treated plants were recovered and were on par with each other. Highest numbers of live larvae (3.73/ plant) were recovered from untreated control plants. No pupae were recovered from $\mathrm{Bb}-45$ and $\mathrm{Bb}-23$ treated plants, 0.07 pupae/ plant from Bb-5a and Bb-7 treated plants, 0.13 pupae/ plant from Bb-14 and Bb-19 treated plants. Highest numbers of pupae (1.26/ plant) were recovered from untreated control plants.

No exit holes were observed in Bb-45 and Bb-23 treated stems. 0.07 exit holes/plant were observed in $\mathrm{Bb}$ 5a treated plants, 0.20 exit holes/plant in Bb-7 and Bb-14 treated plants and 0.27 exit holes/plant in $\mathrm{Bb}-19$ treated plants. Greater numbers of exit holes of 0.60 /plant were observed in untreated control plants (Table 4). 
Table 4. Damage caused by Chilo partellus (second instar larvae) in Beauveria bassiana treated maize plants

\begin{tabular}{|l|l|l|l|l|l|l|l|}
\hline S1 no. & Strains & $\begin{array}{l}\text { Foliar damage } \\
\left(\text { mean rank }^{*}\right)\end{array}$ & $\begin{array}{l}\text { Percent dead } \\
\text { heart }\end{array}$ & $\begin{array}{l}\text { Stem tunneled / } \\
\text { plant }(\mathrm{cm})\end{array}$ & $\begin{array}{l}\text { Number of live } \\
\text { larvae / plant }\end{array}$ & $\begin{array}{l}\text { Number of } \\
\text { pupae/plant }\end{array}$ & $\begin{array}{l}\text { Number of exit } \\
\text { holes / plant }\end{array}$ \\
\hline 1 & Bb5a & $4.33^{\mathrm{a}}$ & $2.2^{\mathrm{a}}$ & $3.03^{\mathrm{a}}$ & $0.13^{\mathrm{a}}$ & $0.07^{\mathrm{a}}$ & $0.07^{\mathrm{ab}}$ \\
\hline 2 & $\mathrm{Bb} 7$ & $9.00^{\mathrm{ab}}$ & $6.66^{\mathrm{b}}$ & $3.51^{\mathrm{a}}$ & $0.13^{\mathrm{a}}$ & $0.07^{\mathrm{a}}$ & $0.20^{\mathrm{ab}}$ \\
\hline 3 & $\mathrm{Bb} 14$ & $15.17^{\mathrm{b}}$ & $11.13^{\mathrm{b}}$ & $4.17^{\mathrm{a}}$ & $0.27^{\mathrm{a}}$ & $0.13^{\mathrm{a}}$ & $0.20^{\mathrm{ab}}$ \\
\hline 4 & Bb19 & $14.00^{\mathrm{b}}$ & $11.13^{\mathrm{b}}$ & $4.33^{\mathrm{a}}$ & $0.27^{\mathrm{a}}$ & $0.13^{\mathrm{a}}$ & $0.27^{\mathrm{b}}$ \\
\hline 5 & $\mathrm{Bb} 23$ & $8.83^{\mathrm{ab}}$ & $6.66^{\mathrm{b}}$ & $2.90^{\mathrm{a}}$ & $0.07^{\mathrm{a}}$ & $0.00^{\mathrm{a}}$ & $0.00^{\mathrm{a}}$ \\
\hline 6 & Bb45 & $5.67^{\mathrm{a}}$ & $2.2^{\mathrm{a}}$ & $2.69^{\mathrm{a}}$ & $0.00^{\mathrm{a}}$ & $0.00^{\mathrm{a}}$ & $0.00^{\mathrm{a}}$ \\
\hline 7 & Control & $20.00^{\mathrm{c}}$ & $28.86^{\mathrm{c}}$ & $13.41^{\mathrm{b}}$ & $3.73^{\mathrm{b}}$ & $1.26^{\mathrm{b}}$ & $0.60^{\mathrm{c}}$ \\
\hline $\mathrm{CD} @ 0.01 \%$ & $* *$ & 4.29 & 3.05 & 0.52 & 0.54 & 0.30 \\
\hline
\end{tabular}

Values in columns followed by the different letter $(\mathrm{a}, \mathrm{b}, \mathrm{c})$ are significantly different with each other according to LSD (P $<0.01)$

*Mean ranks with same letter did not differ at $\mathrm{P}>/ 0.05$.

$* * \mathrm{X}^{2}=14.98$, d.f. $=6, \mathrm{P}>/ 0.05$

Endophytic strains of Beauveria bassiana minimized the damage caused by C. partellus in maize plants and reduced the survival of the pest. Reduction in larval population and reduced damage may be associated with endophytic colonization of $B$. bassiana. Similar results were reported with endophytic B. bassiana strains for European corn borer, Ostrinia nubilalis in maize (Bing and Lewis, 1991), Sesamia calamistis in maize (Cherry et al., 2004), Cosmopolites sordidus in banana (Akello et al., 2008), Sesamia nonagrioides in sorghum (Mantzoukas et al., 2015) and Helicoverpa armigera in tomato (Qayyum et al., 2015). It has been reported (Gurulingappa et al., 2011) that endophytic strains of $B$. bassiana might have produced certain secondary metabolites in the host plant with anti feeding properties and insecticidal activity against the pests leading to mortality/less activity of the pest. The exact mechanism of the effect of endophytic B. bassiana on the herbivorous insects remains to be investigated in detail. The reduction in plant damage caused by $C$. partellus may be due to secretion of metabolites expressed by the endophytic fungi or by induction of plant metabolites by the endophytic fungi. According to Roy et al., (2006) a series of altered behaviors are exhibited by $B$. bassiana infected insects, including reduced feeding. In the present study, endophytic B. bassiana negatively affected the larval feeding and development which resulted in the reduced plant damage.

Our current studies showed that, Beauveria bassiana was able to spread from treated plant part (older) to untreated newly emerged maize plant tissues and provided the protection against borer pest Chilo partellus. Future studies should be undertaken for exploitation of their potential use in management of insect pests.

\section{ACKNOWLEDGEMENTS}

The authors are thankful to the Director, ICAR-National Bureau of Agricultural Insect Resources, Bangalore, Karnataka, India for the constant support during the research work.

\section{REFERENCES}

Akello J, Dubois T, Gold CS, Coyne D, Nakavuma J, Paparu P. 2007. Beauveria bassiana (Balsamo) Vuillemin as an endophyte in tissue culture banana (Musa spp.). $J$ Invert Pathol. 96: 34-42.

Akello, J, Dubois T, Coyne D, Kyamanywa S. 2008. Effect of endophytic Beauveria bassiana on populations of the banana weevil, Cosmopolites sordidus, and their damage in tissue-cultured banana plants. Entomol Exp Appl. 129: 157-165.

Akutse KS, Maniania NK, Fiaboe KKM, Van Den Berg J, Ekesi S, 2013. Endophytic colonization of Vicia faba and Phaseolus vulgaris (Fabaceae) by fungal pathogens and their effects on the lifehistory parameters of Liriomyza huidobrensis (Diptera: Agromyzidae). Fungal Ecol. 6: 293-301.

Ballal Chandish R, Kumar, Pradyumn, Ramani S. 1995. Laboratory evaluation, storability and economics of an artificial diet for rearing Chilo partellus (Swinhoe) (Lepidoptera:Pyralidae). J Entomol Res. 19: 135-141.

Bing LA, Lewis LC. 1991. Suppression of Ostrinia nubilalis (Hübner) (Lepidoptera: Pyralidae) by Endophytic Beauveria bassiana (Balsamo) Vuillemin. Environ Entomol. 20: 1207-1211.

Burges HD. 1998. Formulation of Microbial Biopesticides. Kluwer Academic Publishers, Dordrecht, The Netherlands.

Biswas C, Dey P, Satpathy S, Satya P, Mahapatra BS. 2013. Endophytic colonization of white jute (Corchorus capsularis) plants by different Beauveria bassiana strains for managing stem weevil (Apion corchori). Phytoparasitica. 41: 17-21. 
Cherry AJ, Banito A, Djegui D, Lomer C. 2004. Suppression of the stem-borer Sesamia calamistis (Lepidoptera: Noctuidae) in maize following seed dressing, topical application and stem injection with African isolates of Beauveria bassiana. Int J Pest Management 50: $67-73$.

Dunn OJ. 1964. Multiple comparisons using rank sums. Technometrics 6: 241-252.

Gómez-Vidal S, Lopez-Llorca LV, Jansson HB, Salinas J. 2006. Endophytic colonization of date palm (Phoenix dactylifera L.) leaves by entomopathogenic fungi. Micron. 37: 624-632.

Gurulingappa P, Sword GA, Murdoch G, McGee PA. 2010. Colonization of crop plants by fungal entomopathogens and their effects on two insect pests when in planta. Biol Control 55: 34-41.

Gurulingappa P, McGee PA, Sword GA. 2011. Endophytic Lecanicillium lecanii and Beauveria bassiana reduce the survival and fecundity of Aphis gossypii following contact with conidia and secondary metabolites. Crop Prot. 30: 349-353.

Jalali Sk, Sihgh SP. 2003. Bio-ecology of chilo partellus (swinhoe) (lepibbptera; pyralioae) and. evaluation of its natural enemies - A review. Agric Rev. 24: 79-100.

Jones KD. 1994. Aspects of the biology and biological control of the European corn borer in North Carolina. Ph.D. Thesis, North Carolina State University.

Leckie BM. 2002. Effects of Beauveria bassiana mycelia and metabolites incorporated into synthetic diet and fed to larval Helicoverpa zea, and detection of endophytic Beauveria bassiana in tomato plants using PCR and ITS. M.S. Thesis, (Entomology), Department of Entomology, The University of Tennessee, Tennesse, USA).

Ling J, Ling KLE, Chan KW, French GL. 1987. Computer programs for accurate determination of size of DNA fragments in agarose gels. J Clin Pathol. 40: 692-695.

Mantzoukas SC, Chondrogiannis C, Grammatikopoulos G. 2015. Effects of three endophytic entomopathogens on sweet sorghum and on the larvae of the stalk borer Sesamia nonagrioides. Entomol Exp Appl. 154: 78-87.

Odindo MO, Opondo-Mbai M, Amutalla PA. 1992. Effect of sorghum phenology on the control of Chilo partel- lus with Nosema marucae (Microspora: Nosematidae). Biocontrol Sci Technol. 2: 307-314.

Posada F, Vega FE. 2005. Establishment of the fungal entomopathogen Beauveria bassiana (Ascomycota: Hypocreales) as an endophyte in cocoa seedlings (Theobroma cacao). Mycologia 97: 1195-1200.

Posada F, Vega FE. 2006. Inoculation and colonization of coffee seedlings (Coffeaarabica L.) with the fungal entomopathogen Beauveria bassiana (Ascomycota: Hypocreales). Mycoscience 47: 284-289.

Posada F, Aime MC, Peterson SW, Rehner SA, Vega FE. 2007. Inoculation of coffee plants with the fungal entomopathogen Beauveria bassiana (Ascomycota: Hypocreales). Mycol Res. 111: 749-758.

Powell WA, Klingeman WE, Ownley BH, Gwinn KD. 2009. Evidence of Endophytic Beauveria bassiana in Seed-treated Tomato Plants Acting as a Systemic Entomopathogen to Larval Helicoverpa zea (Lepidoptera: Noctuidae). J Entomol Sci. 44: 391-396.

Qayyum MA, Wakil W, Arif MJ, Sahi ST, Dunlap CA. 2015. Infection of Helicoverpa armigera by endophytic Beauveria bassiana colonizing tomato plants. Biol Control 90: 200-207.

Quesada-Moraga E, Munoz-Ledesma FJ, Santiago-Alvarez C. 2009. Systemic protection of Papaver somniferum L., against Iraella luteipes (Hymenoptera: Cynipidae) by an endophytic strain of Beauveria bassiana (Ascomycota: Hypocreales). Environ Entomol. 38: $723-730$.

Renuka S, Ramanujam B, Poornesha B. 2015. Screening of Beauveria bassiana (Balsamo) Vuillemin isolates against maize Stem Borer, Chilo partellus (Lepidoptera: Pyralidae) and the effect of solid substrates on conidial production and virulence. J Pure Appl Microbiol. 9: 2979-2986.

Renuka S, Ramanujam B, Poornesha B. 2016. Endophytic ability of different isolates of entomopathogenic fungi Beauveria bassiana (Balsamo) Vuillemin in stem and leaf tissues of maize (Zea mays L.). Indian J Microbiol. 56: $126-133$.

Roy HE, Steinkraus DC, Eilenberg J, Hajek AE, Pell JK. 2006. Bizarre interactions and endgames: entomopathogenic fungi and their arthropod hosts. Annu Rev Entomol. 51: 331-357. 
RENUKA et al.

Tefera T, Vidal S. 2009. Effect of inoculation method and plant growth medium on endophytic colonization of sorghum by the entomopathogenic fungus Beauveria bassiana. BioControl 54: 663-669.
Wagner BL, Lewis LC. 2000. Colonization of corn, Zea mays, by the entomopathogenic fungus Beauveria bassiana. Appl Environ Microbiol. 66: 3468-3473. 